\title{
Shigella sonnei: virulence and antibiotic resistance
}

\author{
Ahtesham Ahmad Shad ${ }^{1}$ (i) $\cdot$ Wajahat Ahmed Shad ${ }^{2}$
}

Received: 24 June 2020 / Revised: 27 August 2020 / Accepted: 2 September 2020 / Published online: 14 September 2020

(c) Springer-Verlag GmbH Germany, part of Springer Nature 2020

\begin{abstract}
Shigella sonnei is the emerging pathogen globally, as it is the second common infectious species of shigellosis (bloody diarrhoea) in low- and middle-income countries (LMICs) and the leading one in developed world. The multifactorial processes and novel mechanisms have been identified in $S$. sonnei, that are collectively playing apart a substantial role in increasing its prevalence, while replacing the S. flexneri and other Gram-negative gut pathogens niche occupancy. Recently, studies suggest that due to improvement in sanitation $S$. sonnei has reduced cross-immunization from Plesiomonas shigelliodes (having same $\mathrm{O}$-antigen as $S$. sonnei) and also found to outcompete the two major species of Enterobacteriaceae family (Shigella flexneri and Escherichia coli), due to encoding of type VI secretion system (T6SS). This review aimed to highlight S. sonnei as an emerging pathogen in the light of recent research with pondering aspects on its epidemiology, transmission, and pathogenic mechanisms. Additionally, this paper aimed to review S. sonnei disease pattern and related complications, symptoms, and laboratory diagnostic techniques. Furthermore, the available treatment reigns and antibiotic-resistance patterns of $S$. sonnei are also discussed, as the ciprofloxacin and fluoroquinolone-resistant $S$. sonnei has already intensified the global spread and burden of antimicrobial resistance. In last, prevention and controlling strategies are briefed to limit and tackle S. sonnei and possible future areas are also explored that needed more research to unravel the hidden mysteries surrounding S. sonnei.
\end{abstract}

Keywords Shigella sonnei $\cdot$ Shigella flexneri $\cdot$ Escherichia coli $\cdot$ LMICs $\cdot$ Virulence $\cdot$ Antimicrobial resistance

\section{Introduction}

The Shigella is the Gram-negative rod, facultatively anaerobic, non-spore forming and non-motile bacterial genera belongs to Enterobacteriaceae family and comprise of four major species $S$. dysenteriae, S. boydii, S. flexneri and $S$. sonnei (Chatterjee and Raval 2019). Shigella species stand apart from Enterobacteriaceae due to their unique nature, mechanisms of pathogenesis and evolutionary history (The et al. 2016). Kiyoshi Shiga in 1897 from Japan, first isolated the highly virulent strain $S$. dysenteriae that produce exotoxins (Trofa et al. 1999; Lampel et al. 2018). The other species were discovered later, S. flexneri in 1899, S. sonnei

Communicated by Erko stackebrandt.

Ahtesham Ahmad Shad

ahtesham.ashad@yahoo.com

1 Institute of Microbiology, University of Agriculture, Faisalabad 38040, Pakistan

2 Department of Biochemistry, University of Agriculture, Faisalabad, Pakistan by Carl Olaf Sonne in 1906 and Shigella boydii in 1921 (Barceloux 2008).

Because of diverse antigenicity based on lipopolysaccharides (LPS), O-antigen components in cell wall, Shigella species has further serotypes and sub-serotypes. The serotype 1 of Shigella dysenteries (formerly Shigella bacillus), has 15 types, S. flexneri has 19, S. boydii has 20, however, S. sonnei has just only 1 serotype (Wu et al. 2019). Several studies indicate that, the Shigella spp. are geographically distributed based on the economic development of countries (Anderson et al. 2016). The most of the Shigella infection are caused by $S$. flexneri as highlighted as an emerging pathogen in a recent review (Nisa et al. 2020). In past, $S$. flexneri infections have been associated worldwide (Gentle et al. 2016), while $S$. sonnei has been found to be in association with the developed world only.

The sequencing of eight housekeeping chromosomal genes showed that the Shigella spp. contain three major clades (C1, C2 and C3) and an outgroup member to these clades named S. sonnei (Pupo et al. 2000). However, a study assumes that $S$. sonnei emerged later than the other types of Shigella spp. and are more in developed world than 
developing world, probably, because low-resource countries show more immunity to $S$. sonnei as exposure of faecal contaminated water that contains Pleisiomonas Shigelloides O17 having identical antigen to S. sonnei (Shepherd et al. 2000). A more recent genomic study indicated that, S. son$n e i$ emerged from $E$. coli in central Europe $\sim 1500$ AD (Holt et al. 2012) and spread intercontinentally through travellers. S. sonnei significantly dependent on economic and industrial development of regions (Qiu et al. 2015) and now showing dominance over $S$. flexneri due to several mechanisms. However, $S$. sonnei rate of infections trend is replacing $S$. flexneri and has been changing substantially over time, shifting towards low- and middle-income countries (LMICs), particularly in Asia (Thompson et al. 2015).

Globally, Shigella spp. are strict human pathogens, accounts for shigellosis (bloody diarrhoea) and associated with huge proportion of morbidity and mortality (Khalil et al. 2018; Kotloff et al. 2018). The annual deaths estimated to be 212438 in group of all ages due to Shigella infections and children of age $<5$ are more prone to shigellosis leading to 75 million cases each year (Khalil et al. 2018). Moreover, military forces and international travellers are also susceptible to Shigella (Porter et al. 2017). The encoding of T6SS in $S$. sonnei favours the propagation and survival efficiently as compare with $S$. flexneri (lacks T6SS), while also commensally target $E$. coli (Anderson et al. 2017).

$S$. sonnei has been found to adapt and equipped with antimicrobial resistance genes more profoundly through mobile genetic elements (MGEs) such as plasmids, transposons, insertion sequences and genomic islands (Muthuirulandi Sethuvel et al. 2017) as compared with S. flexneri (Thompson et al. 2015). The synergistic effect of antimicrobial resistance genes (ARGs) alongside with integrons (genetic elements that acquire or exchange exogenous DNA, called as gene cassettes by site-specific recombination) further increases the emergence and survival rate (Ahmed et al. 2006). In another study ubiquitously existing, free living amoeba called Acanthamoebae castellanii has found to phagocytosize $S$. sonnei protecting it from chlorination and environmental damage (Saeed et al. 2009), however, contrary to this, in a recent study, it has been shown that although $A$. castellanii phagocytosize $S$. sonnei but it does not be able to survive or grow in the cytosol of $A$. castellanii (Watson et al. 2018).

Additionally, it has also been found that the O-antigen of $S$. sonnei inhibits internalization, vacuole escape and inflammasome activation, this different approach further stands out $S$. sonnei from other Gram-negative enteropathogenic E. coli and Salmonella spp. (Watson et al. 2019). Thus, in the light of such versatile weapons, $S$. sonnei has an edge over the closely related and to the different species as well (Starling 2017). Therefore, the spectrum of recent studies actively demands for looking more alternative approaches in determining and characterization of the actual cause of $S$. sonnei infections persistence.

This review aimed to highlight the $S$. sonnei, as an emerging pathogen in the light of recent research and findings. The gaps which recent studies has filled and further urged to look for more possible underlying mysterious mechanisms including epidemiological features, and evolving mechanisms of antimicrobial resistance patterns of $S$. sonnei are discussed. As, the global expansion of ciprofloxacin and fluoroquinolone-resistant S. sonnei (De Lappe et al. 2015; Chung The et al. 2016, 2019; The and Baker 2018) exacerbated the antimicrobial resistance issue worldwide. The comprehensive knowledge about $S$. sonnei attempted to be documented here, that lead to establish a clearer picture in understanding of this deadly pathogen as to overcome and tackle it has been a serious emerging problem.

\section{Epidemiological view of S. sonnei}

S. sonnei accounts for up to $80 \%$ of all the Shigella infections in developed world, particularly in North America and Europe (Gu et al. 2012) and has caused several outbreaks, for example, in California between 2014 and 2015 (Kozyreva et al. 2016). For instance, S. sonnie has significantly contributed to foodborne outbreaks as well in America and Canada, highlighting the food items as the major source (Lee et al. 1991; Naimi et al. 2003; Kimura et al. 2004). In Spain, a study associated the $S$. sonnei infections upon the consumption of fresh pasteurized milk cheese (García-Fulgueiras et al. 2001). In Australia, S. sonnei prevalence rate has been identified up to $55.6 \%$ of all Shigella infections in year 2010 (OzFoodNet Working Group 2012).

In a different study, the foodborne outbreak of $S$. sonnei has also been reported and raw carrots were identified as the potential vehicle among air passengers departed from Hawaii to Japan (Gaynor et al. 2009), pointing towards the expanding landscape of transmission horizon. Prior to this, a study has pinpointed $S$. sonnei (from a packing shed of baby corn in Thailand) as the potential cause of foodborne outbreak in Denmark and Australia (Lewis et al. 2009). Additionally, the foodborne outbreaks due to $S$. sonnei has also been reported in youth-trip from Austria (Kuo et al. 2009) and associated the consumption of raw peas as a potential source of infection in Denmark (Muller et al. 2009).

However, the global trend of infections due to S. son$n e i$ has changed drastically over time from developed to developing countries due to evolving mechanisms and different infection causing modes in $S$. sonnei (Torraca et al. 2020). The frequency of outbreaks and respective severity differ across regions due to multifactorial elements based on geography, climate, host-pathogen relationships, and corresponding controlling strategies. A study from Bangladesh, estimated the trending changes of Shigella spp. and observed 
that the prevalence of S. sonnei increased from $7.2 \%$ to $25 \%$ in 2001-2011, respectively (Ud-Din et al. 2013).

Recently, three main lineages of S. sonnei (I, II, III) have been identified. $S$. sonnei evolved rapidly from Europe and spread as multi-drug-resistant (MDR) single lineage to other continents dominantly (Holt et al. 2012; Anandan et al. 2017). The single clone was named as "Global lineage III" (see Table 1).

In Taiwan, the rate of infections caused by Shigella is rare, while $S$. sonnei reported cases were 16 from 200 to 2003 and only one case reported in 2006. The genotypic data showed that, the reducing rate of infection was probably due to limited travelling and contact between villages population, lead to conclude that public health intervention as one of the best controlling strategy (Ko et al. 2013). Furthermore, the serotype shift has been documented in a recent research note and accounted the prevalence of $S$. sonnei infections steadily increased from 2003 to 2011 (17.4-58.2\%) in China (Qiu et al. 2015).

A recent broad-spectrum study from Korea, investigated the Shigella spp. dysentery infections rate and reported the steady increase of S. sonnei infections from 1954 to 2004 (50 years), thus concluding the substantial change of $S$. flexneri to S. sonnei serotype (Pai 2020). S. sonnei also found predominantly in one study from Africa, four in Asia and two in South America (Kahsay and Muthupandian 2016).

\section{Transmission}

The very low infectious dose rate of about of 1-100 cells results in severe outbreaks and transmission. S. sonne $i$ along with other Shigella species shares the common mode of reservoirs and transmission pattern, including water, food, wild animals, birds, insects, and amoeba (Bridle 2013). Humans are the primary host and transmission primarily occurred through fecal-oral route. The infections caused by Shigella spp. are highly contagious and considered as most infectious as compared to other bacterial entero-pathogens (DuPont 2014). However, the bacterium cannot survive out long without host for continuous transmission (Niyogi 2005). The contamination of water and food, fomites, poor sanitation, and ecological conditions also aid in the persistence of $S$.

Table 1 Dissemination of MDR S. sonnei Global lineage III from Europe (Holt et al. 2012)

\begin{tabular}{ll}
\hline Regions/Country & Year \\
\hline Korea & 1978 \\
South America & 1982 \\
Africa & 1982 \\
Middle East & 1983 \\
Central Asia & 1986 \\
Vietnam & 1990,1997 \\
\hline
\end{tabular}

$M D R$ multi-drug resistant sonnei that result in emerging of severe kind of outbreaks (Taneja and Mewara 2016). For instance, only $40 \%$ of Indian population has access to good sanitation system, this further escalate the infections rate in the region (The World Bank 2015). S. sonnei has ability to turn into viable but non-culturable form (VBNC), thus aiding in the survival and then transmission later on, when conditions become favourable (Nicolò et al. 2011).

Shigella sonnei possess capability to survive seven weeks on soiled linen, 5 days in freshwater environment, while $12-30 \mathrm{~h}$ in salt water and carriers can excrete up to 2 weeks after infection or longer occasionally (Nisar et al. 2014). The seasonality also affects the rate of $S$. sonnei infection, as probably high in summer and rain, while in tropical climatic regions, it is present throughout the year (Ashkenazi and Cohen 2013). The bacterium virulence genes become activated and expressed at $30-37{ }^{\circ} \mathrm{C}$, in $\mathrm{pH} 7.433$ and mild osmotic pressure (Dorman and Porter 1998). The S. son$n e i$ frequently causes episodes in populated organizations, counting primary schools, military camps (Lee et al. 2003; Wei et al. 2007). Travelling, prison and asylum houses have been significantly attributed to $S$. sonnei transmission and outbreaks (Baker et al. 2016; Al-Dahmoshi et al. 2020). Muscus domestica (common house fly) is also a major vector in the transmission of S. sonnei infections (Gupta et al. 2012).

Moreover, sexual transmission of $S$. sonnei particularly in gay, bisexual and men sex with men (GBMSM) communities has been reported in Europe, Asia, North America and Oceania (Baker et al. 2015; Mook et al. 2016; Liao et al. 2017). The person-to-person transmission of $S$. sonnei has also been common in Europe, particularly in England (Morgan et al. 2006; McDonnell et al. 2013; Simms et al. 2015), suggesting $S$. sonnei as the major health problem causing the burden of gastrointestinal infections (Dallman et al. 2016). Additionally, four distinct chains of $S$. sonnei infections in United Kingdom (UK) has been identified showing little difference in genetic diversity (Baker et al. 2018a). The HIV (human immunodeficiency virus)-infected patients also serve as a reservoir for the transmission of $S$. sonnei, as due to the use of antiretroviral therapy parasitic pathogens become more common (Wanyiri et al. 2013).

A recent study opened a new dimension of 'gender' to explore the rate of $S$. sonnei infections. The study suggested a different transmissibility pattern of shigellosis among male and females. The female-male transmission has been found dominant, because females generally carry out more tasks such as cooking in the home. While to children ( $\leq 5$ years), the route of transmission were elder people $(\geq 60)$, as grandparents care for children as a custom in China. This highlighted the urgent need of interventions to be applied in females and elder people (Zhao et al. 2020). However, the previous reports also support that the males are more 
prone to shigellosis and incidence rate is higher than females (Xiao et al. 2014; Chang et al. 2016; Yan et al. 2018). This is supported by a study, indicating that the female sanitary state is more than males (Chompook et al. 2006). But this impact cannot be ignored that the various modes of possible transmission like food, water and inter-personal connection has been interrupted and show relative incidences entirely differently among the different age groups (Hao et al. 2019). In addition, a more recent data on antibiotic-resistant enteric pathogens, suggested investment in WASH (Water, Sanitation, and Hygiene) measures to tackle the global burden of enteric infections (Shakoor et al. 2019).

\section{Pathogenesis and virulence mechanisms of S. sonnei}

Shigella sonnei possesses multiple well-established and unique pathogenic mechanisms (Caboni et al. 2015; Mahmoud et al. 2016; Anderson et al. 2017) (see Fig. 1). All the four Shigella species can cause disease in human (Livio et al. 2014). The survival of $S$. sonnei intracellularly, sabotaging the phagocytic killing and evading of host immune system, particularly inflammatory responses are the fundamental processes of its pathogenesis. For example, inhibition of host pro-inflammatory responses and modulation in the regulation of B-cells and T-cells. These mechanisms and evolving nature of $S$. sonnei can result in the persistence of infection for longer period (Ashida et al. 2015).
Shigella sonnei successful invasion is based on the overcoming of two gut-specific barriers, the gut microbiota and mucus layer (Anderson et al. 2016), as the commensal pathogens competitively act on survival and proliferation. This competitive situation modulates the host immune response, due to the toxins and antimicrobial responses (Baker and The 2018). The invasion plasmid antigen (ipaH) and invasionassociated locus ( $\mathrm{ial}$ ) facilitates the internalization, survival and growth in intestinal cells (Johnson 2017). A study from Vietnam (Thiem et al. 2004), reported the $100 \%$ prevalence of ipa $\mathrm{H}$ gene in $S$. sonnei, while it is detected very low from Kenya (Nyanga et al. 2017). These genes are the effectors of T3SS (type 3 secretion system).

Interestingly, prior to release, its effector proteins $S$. sonnei first adhere to host cell diligently, despite in the absence of classical adhesins (Killackey et al. 2016). The recent study showed that the surface protein IcsA (actin polymerizing factor), activated by bile salts, function as an adhesin and play a pivotal role in the attachment to host after the initial activation of T3SS (Brotcke Zumsteg et al. 2014). This novel adhesin advances the pathogenesis pattern and further, the g4C (Group 4C) capsule protects from serummediated killing. The $\mathrm{g} 4 \mathrm{C}$ capsule is made up of unknown lipid anchor, rather than the known lipopolysaccharides (Caboni et al. 2015). The g4C capsule has high molecular weight and due to its similarity with LPS-Ag, referred as O-Ag capsule (Whitfield 2006).

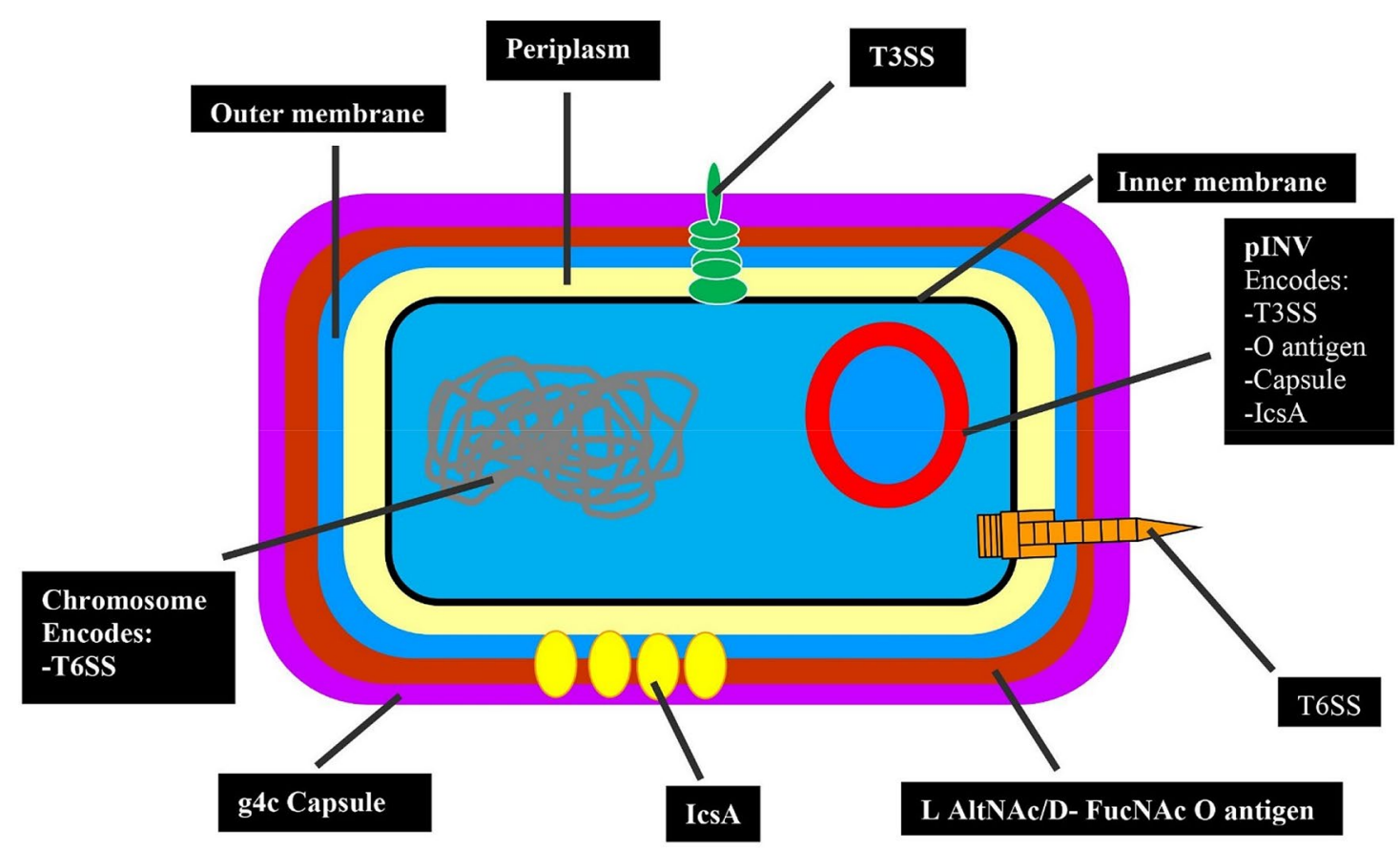

Fig. 1 Schematic representation of S. sonnei virulence arsenal (Torraca et al. 2020). T3SS host cell invasion, IcsA actin based mortility, T6SS Bacterial competition and niche occupancy, $g 4 c$ and $O$ antigen resistance to phagocytosis, complement-mediated lysis and phogolysosomal degradtion. L-ALTNAC 2-acetamido-2-deoxy-L-altruronic acid, $D$-FUCNAC N-acetyl-2-acetamido-4-amino-2,4-dideoxy-D-fucose 
The effector proteins (OspE1 and OspE2), secretion is further promoted by bile salts, that remain intact with the bacterial outer membrane, thus enhances attachment to other polarized cells (Faherty et al. 2012). Moreover, deoxycholate (bile salt), make the final assembly of T3SS in activation-ready state (Stensrud et al. 2008). At the distal tip end of T3SS are components IpaB, IpaC and IpaD. The IpaD assemble the IpaB and IpaC on to the needle, while IpaB and $\mathrm{IpaC}$ are hydrophobic proteins in nature and triggers the formation of pore in host cell to deliver effector proteins (Veenendaal et al. 2007).The host membrane cholesterol play a major role in the interaction with IpaB to facilitate and promote the insertion and T3SS activity (Hayward et al. 2005).

The T3SS components (IpaB and IpaD), promote binding to filopodia (cytoplasmic projections) and aid in interaction and invasion (Romero et al. 2011). The IpaB function as a molecular plug to block the secretion from T3SS prior to its insertion and removed, while inserted into host membrane (Roehrich et al. 2010). The other T3SS-dependent effector virulence factors include IcsB (inhibit autophagy), IpaA (actin depolymerization) and OpsD3 that has entero-toxic activity (Du et al. 2016).

The bacterium reaches its primary target, the colonic epithelium by invading through $\mathrm{M}$ cells (microfold) of the gutassociated lymphoid tissue (GALT) and mucosa-associated lymphoid tissue (MALT), located in the Peyer's patches of small intestine (Phalipon and Sansonetti 2007). Then, bacteria cause inflammatory colitis (Ashida et al. 2015). Shigella sonnei act against the suppression of inflammation by the host, releasing the effector proteins against MAPK (Mitogen-Activated Protein Kinases) and NF- $\mathrm{KB}$ (Nuclear Factors) signaling pathways. In addition, bacterium also inhibit pro-inflammatory cytokines, for example, IL-8 (Interleukin-8) epigenetically (Ashida et al. 2011).

In a genomic study, the sequencing of $S$. sonnei strain revealed that the genome (chromosomal and plasmid DNA) of 4,546,505 bp size containing biosynthetic genes of lipopolysaccharide (Deutsch-Nagy et al. 2018). A recent zebrafish model study of $S$. sonnei infection revealed that S. sonnei $\mathrm{O}$-antigen resist acidification by phagolysosome and enhance neutrophils cell death, hence found to be more virulent than $S$. flexneri due to its acquired O-antigen oligosaccharides from environmental bacteria Plesiomonas shigelliodes. Additionally, suggesting that the increase of phagolysosomal acidification and frequent innate immune system exposure can decrease $S$. sonnei by neutrophils (Torraca et al. 2019).

There are two distinct unusual sugars are present only on S. sonnei O-Ag (-acetamido-2-deoxy-L-altruronic acid and 2-acetamido-2-deoxy-L-fucose) (Liu et al. 2008). Both, lipopolysaccharide, and capsule contain O-Ag, reduce $S$. sonnei uptake, however, a recent study further thrown light in this dimension saying $S$. sonnei has adapted its extracellular lifestyle and survival mode by developing multiple O-Ag layers on its surface (Watson et al. 2019). Furthermore, $S$. sonnei also down-regulate the antimicrobial peptides ( $B$-defensin hBD-3) and chemokines such as CCL20 (C-C Motif Chemokine Ligand 20), thus turning dendritic cells into defective state (Al-Dahmoshi et al. 2020).

In addition, a large virulence plasmid (pINV) of size $220 \mathrm{~kb}$ encodes the proteins that make needle-like macromolecular structure, this enables the transmission of effector proteins from bacterium to host eukaryotic cell directly (Killackey et al. 2016). Type 3 secretion system (T3SS) enables $S$. sonnei to enter in the host epithelial cells by rupturing its vacuolar membrane, then the bacterium proliferates in cytosol and spread cell-to-cell (Mellouk and Enninga 2016). However, the exact molecular nature and mechanism by which the bacteria rupture vacuolar membrane still demands precise understanding (Carayol and Van Nhieu 2013).

In addition to the virulence plasmid, a small region of chromosome "Pathogenicity Islands" also contributes to the pathogenesis and virulence. This pathogenic island is present among Shigella spp. and are highly diversified (Yang et al. 2005). A recent study reported the functional type 6 secretion system (T6SS) presence in S. sonnei (encoded by chromosome), that gives $S$. sonnei an advantage in a nichespecific environment over E. coli, S. flexneri and other closely related species. T66S predominate $S$. sonnei colonization in host and help it during interbacterial competition (Anderson et al. 2017). Shigella sonnei found to be killing competitors near the surface of colon epithelial cells, thus suggesting T6SS-mediated killing as potential mechanism of uprising its global prevalence.

Pyroptotic cell death (highly inflammatory programmed cell death) play a major role in the pathogenesis of $S$. flexneri (Bergsbaken et al. 2009), that help in escaping the macrophage-mediated killing, inducing local inflammation and evasion of epithelial cells from basolateral side. Likewise, S. sonnei $i$ also induces macrophages pyroptosis through caspase 1. Additionally, the internalization of $S$. sonnei into macrophages is dominantly found to be through phagocytic uptake of macrophages, rather than evasion through T3SS mechanism, as found predominantly in S. flexneri (Watson et al. 2019). Moreover, S. flexneri can activate NLR4C and NLRP3 inflammasomes (multiprotein intracellular complex, that detect pathogens and activate pro-inflammatory response) (Suzuki et al. 2014). It is unclear that S. sonnei releases the same inflammasome or not and to which its benefit, to host or the bacteria itself.

Shigella sonnei also possess antibacterial mechanisms. $S$. sonnei has potential to enable proton consumption system, resist host antimicrobial peptides (Mattock and Blocker 2017), produce colicins (a toxin produces by coliform bacteria) and mucinases (enzymes to degrade 
mucins) that kills small range of phylogenetically related bacteria, thus making $S$. sonnei more favourable in the colicin-mucinase sensitive strains. A study from India reported the $93 \%$ presence of at least one colicin-coding plasmid, showing its high level of threatening pathogenic trait (Calcuttawala et al. 2015). Another study from Bhutan showed that, all tested strains of $S$. sonnei carried ColE plasmid, to produce colicins (Ruekit et al. 2014).

A different but homologous pic (S. flexneri 2A protein) is also expressed by $S$. sonnei, belonging to SPATE (Serine, Protease, AutoTransporters of Enterobacteriaceae) family that secrete another protein (SepA). A study suggested that, SepA play role in the destabilization of host intestinal epithelial integrity (Maldonado-Contreras et al. 2017).

Recently, first time the completely assembled whole genome of a hybrid pathotype Shiga toxin (Stx) producing $S$. sonnei has been documented. S. sonnei strain found to be carried Stx 1 inducible encoding prophage (genetically $S$. sonnei do not fabricate Shiga toxin), which further draw attention towards the potentially evolving and emerging virulence capabilities of S. sonnei (Sváb et al. 2017). Therefore, there is no ambiguity in the fact that, the global shifting pattern of Shigella infections are multifactorial and depend on several host, environmental, bacterial rapid mutational, and evolutionary mechanisms. However, in the light of above-mentioned virulence and pathogenic mechanisms, it is easy to inference that $S$. sonnei has become a potential pathogen, increasing its global emergence and burden.

\section{Diseases and other complications}

After the invasion of colon epithelial cells, S. sonnei cause bloody diarrhoea or "Shigellosis". In response, the host cell releases the pro-inflammatory cytokines (particularly IL-8), and cascades of reaction started at the infection site by recruiting of polymorphonuclear cells (PMNs), such as neutrophils. These PMNs destroy the gut mucosa lining and thus promote further invasion (Williams and Berkley 2018).

There are some other complications, that are resulted in infection due to $S$. sonnei such as seizures, electrolyte imbalance, leukemoid reactions, intestinal perforation, toxic megacolon, arthralgia, rectal prolapse, while in severe cases sepsis and life-threatening haemolytic-uremic syndrome (HUS) (Ashkenazi 2004; Christopher et al. 2010). Immunocompromised, elderly age group people and young children are more prone to complications, like mucosal ulceration, rectal bleeding, and drastic dehydration (Bliven and Lampel 2017). Reiter's syndrome (reactive arthritis ReA) can also develop following the infection from S. sonnei (Hannu et al. 2005).

\section{Symptoms and diagnostic techniques}

The infectious diarrhoea results in the loss of water and electrolyte imbalance, with an abdominal pain, cramping, fever, vomiting; tenesmus (straining during bowel movements), pus and bloody mucoid stools (Nygren et al. 2013). The usual incubation period is 3 days (normally 1-7 days) and symptoms last for almost about 1-2 weeks (Lampel 2012). In endemic regions, the patients become asymptomatic, developing no infection but shed bacterium in stools for longer duration.

The stool culturing and microscopy are the cheap, fast, and easy method to detect the strains of S. sonnei. The PMNs in stools sample can be revealed with the help of methylene blue. The most suitable method to isolate and differentiate $S$. sonnei is microbiological culturing. The pINV plasmid of $S$. sonnei is highly unstable when cultured in vitro, hence $S$. sonnei gives two different appearances when cultured on Congo Red Agar. The small smooth red colonies (retaining plasmid), because of expressing T3SS and O-Ag, while large irregular rough white colonies (loosing plasmid) also formed (Torraca et al. 2020). Multiplex polymerase chain reaction (PCR), technique is also available commercially (Kimberlin et al. 2015). The culture-based approaches inherently possess low sensitivity, as the resistance shown by $S$. sonnei to ciprofloxacin, erythromycin and azithromycin has become a serious problem (Tang et al. 2018).

The routine-based sequencing methodologies and to afford the respective cost of sequencing-based diagnosis is also among the major constraint for the individual health care facilities and institutes apart from research centres in LMICs (low- and middle-income countries). Therefore, it has become very important to evaluate susceptibility pattern and modify treatment according to the results obtained. Pathogen-specific rapid diagnostic assay are now available to detect O-Ag (Gonzalez and McElvania 2018), however, culture-independent diagnostic tests (CIDTs), also do not detect antimicrobial resistance profile (Fang and Patel 2017).

\section{Treatment options}

The majority of Shigella infections are self-limited but in severe cases can be fatal if left untreated. Serotype-specific protective immunity can also be developed against $\mathrm{O}-\mathrm{Ag}$ in the host, automatically over the various exposures (Barnoy et al. 2010). Antimicrobial use is the routine way strategy to limit infection, increase recovery and reducing the transmission. Ampicillin, streptomycin, tetracycline, sulphonamide, and trimethoprim are the common drug of choices against $S$. sonnei. But, over the span of time, $S$. sonnei has become resistant to these antimicrobials. In areas, where ampicillin and co-trimoxazole resistant strains are present, the use of 
fluoroquinolones and azithromycin were advocated (Tribble 2017).

Ciprofloxacin and fluoroquinolone had been recommended by WHO for the effective treatment purpose. However, the widespread use of ciprofloxacin and fluoroquinolone has led to emerge the resistance to these antimicrobials also. In late 1990s, ciprofloxacin-resistant S. sonnei emerged, and spread throughout the Asia within just first decade of century (The and Baker 2018). Rifaximin and rifamycin (nonabsorbable) are effective drug of choice in traveller's diarrhoea (TD), while not helpful in invasive infections. Interestingly, the use of rifamycin potentially reduced the rate of resistance among gut microbiota in comparison to ciprofloxacin treatment (Steffen et al. 2018).

Probiotics has been proved to be as a great source of potential to tackle diarrhoea duration (Basu et al. 2009). Interestingly, using guidelines Lactobacillus rhamnosus GG and Saccharomyces boulardii is recommended for therapeutic purpose (Husby et al. 2012). In another study, 16 out 91 tested lactobacilli showed potent antibacterial activity (Zhang et al. 2011, 2012). But probiotic use and severity level differ with host and are not recommended alternatively over antibiotics in severe and moderate diarrhoea, because of the lack in comprehensive knowledge about probiotic-pathogen specificities (Shakoor et al. 2019). The recombinant probiotics targeting the specific pathogens are in developing phase and if come to clinical use, will effectively reduce the pressure of antibiotics (Mathipa and Thantsha 2017).

To date, there is no licensed vaccine available against $S$. sonnei. The inactivated whole cell and subunit vaccines have also been trialled for the prevention against shigellosis (Kaminski and Oaks 2009), a trial of conjugated vaccine S. sonnei-rEPA (Shigella sonnei O-specific polysaccharide bound to Pseudomonas aeruginosa recombinant exoprotein A), one injection found to provide significant immunity against S. sonnei shigellosis (Cohen et al. 1997). An experimental trivalent vaccine has been made containing O-Ag and a pentavalent vaccine also has been proposed, hypothetically that can be effective against majority of shigellosis (Levine et al. 2007).

Phage therapy is another pivotal option against shigellosis caused by $S$. sonnei. Bacteriophages use has several advantages as specificity to bacteria without disturbing the normal microbiota, bactericidal to antibiotic-resistant pathogens, replication at site and self-limiting (Jamal et al. 2015). Nanoparticles (NPs) are also opening a new window to look for more therapeutic options due to their bactericidal activity against the pathogenic bacteria. NPs destroy the structural integrity of cell and generate oxygen free radicals. Copper oxide NPs has recently shown promising approach towards $S$. sonnei and has been recognized as potential antimicrobial agent (Babaei et al. 2017). Organic acids (citric, acetic, lactic, malic) use also has been regarded as safe by the US
Food and Drug administration, as they are antimicrobial and inactivate bacteria. The research showed that the synergistic effect of malic and lactic acid significantly reduced $S$. sonnei from 4.53 and $3.25 \log \mathrm{CFU} / \mathrm{mL}$, respectively (Zhou et al. 2007). Carvacrol (phenol) and their combinations with organic acids also found to be as potential weapon against S. sonnei.

\section{Antimicrobial resistance pattern of S. sonnei among different classes of antibiotics}

World Health Organization (WHO) first ever published its list of antibiotic-resistant pathogens in 2017 (Tacconelli 2017). Shigella was a priority pathogen among other 12 families of bacteria, that pose significant threat to the public health (Tillotson 2018). The horizontal gene transfer mechanisms and dissemination through mobile genetic elements (MGEs), such as resistance plasmids (R-plasmids), integrons, transposon and also the presence of pathogenic islands on chromosomes has risen up the worldwide transmission and emergence of MDR strains of S. sonnei (Ranjbar and Farahani 2019). In a study, improving water supplies and dissemination of MGEs are predicted to be as the major cause of $S$. sonnei global expansion (Thompson et al. 2015).

Plasmids are one of the major importance in the process of horizontal genetic exchange, thus facilitating the spread of antimicrobial resistance genes. S. sonnei like all enteric pathogens has a potential to adapt and survive in the environment, predominantly in aquatic environments, like sewage and wastewater. The inappropriate sanitation then leads to the contamination of irrigated and drinking water. Thus, resulting in the possible transmission and genetic exchange between strains (Byarugaba 2004). For instance, genes of carbapenemase encoding $b l a_{\mathrm{NDM}-1,}$, extended spectrum beta-lactamase $b l a_{\text {СТХ-M }}$ and currently ongoing challenge of mcr-1(resistance to colistin), has revived the issue of antimicrobial resistance horribly (Cantón et al. 2012; Johnson and Woodford 2013; Schwarz and Johnson 2016). Plasmidmediated transferring of resistance genes (Table 2) in $S$. sonnei has become a common and potential source in the emergence of resistance to antimicrobial regimes (Das and Mandal 2019).

Furthermore, the emergence of resistance to cephalosporins, beta-lactam, macrolides (erythromycin and azithromycin), has left over no empirical choice for treatment (Shakoor et al. 2019). Particularly, in MSM (men sex with men) population the emergence of azithromycinresistant, ciprofloxacin-resistant, and ceftriaxone-resistant $S$. sonnei has intensified the situation as because of its global transmission (Baker et al. 2015). The resistance to third generation cephalosporins and azithromycin has also been reported from Europe, America and Australia 
Table 2 Plasmid-mediated antimicrobial resistance genes prevalence of $S$. sonnei from selected publications

\begin{tabular}{|c|c|c|c|}
\hline Genes & Prevalence (\%) & Country & References \\
\hline \multirow[t]{2}{*}{ bla-CTX-M-1 } & $78.5(11 / 14)$ & Iraq & (Auda 2014) \\
\hline & $15(21 / 140)$ & China & (Zhang et al. 2014) \\
\hline bla-СТX-M-15 & 100,11 & India & (Anandan et al. 2017) \\
\hline \multirow[t]{3}{*}{ bla-OXA-1 } & $5.8(1 / 17)$ & India & (Pazhani et al. 2008) \\
\hline & 7.8 (11/140), 100 & China & (Zhang et al. 2014) \\
\hline & & & (Zhu et al. 2018) \\
\hline \multirow[t]{4}{*}{ bla-TEM-1 } & $20(3 / 15)$ & Brazil & (Peirano et al. 2005) \\
\hline & 2.8 (4/140), 100 & China & (Zhang et al. 2014) \\
\hline & & & (Zhu et al. 2018) \\
\hline & 59 & Chile & (Toro et al. 2005) \\
\hline$d h f r 1 \mathrm{~A}$ & 49 & Spain & $\begin{array}{l}\text { (Delgado and Otero } \\
1988 \text { ) }\end{array}$ \\
\hline \multirow[t]{2}{*}{ SulII } & 100 & Brazil & (Peirano et al. 2005) \\
\hline & 56 & India & (Anandan et al. 2017) \\
\hline \multirow[t]{2}{*}{$a a c\left(6^{\prime}\right)-I b-c r$} & $5.8(1 / 17)$ & India & (Pazhani et al. 2008) \\
\hline & $100,4.2(14 / 337)$ & China & $\begin{array}{l}\text { (Zhu et al. 2018), } \\
\text { (Gu et al. 2017) }\end{array}$ \\
\hline \multirow[t]{2}{*}{$q n r \mathrm{~S}$} & 100 & India & (Anandan et al. 2017) \\
\hline & $2.1(7 / 337)$ & China & (Gu et al. 2017) \\
\hline$q n r \mathrm{~B}$ & $2.7(1 / 37)$ & India & $\begin{array}{l}\text { (Bhattacharya et al. } \\
\text { 2011) }\end{array}$ \\
\hline qерА & $0.6(2 / 337)$ & China & (Gu et al. 2017) \\
\hline$m c r-1$ & 100 & Vietnam & (Thanh et al. 2016) \\
\hline
\end{tabular}

in MSM and HIV positive population (Baker et al. 2015; Ingle et al. 2019). While, azithromycin resistance measurement has no standard guidelines, thus emanating an issue in its actual surveillance and monitoring (Brown et al. 2017). Additionally, according to a systematic review study, the rate of infections due to ESBL-producing and cephalosporin-resistant Shigella spp. particularly S. sonnei has increased in Asia than from Europe and America since 1998-2012 (Gu et al. 2015).

Plasmid incompatibility typing of isolates has a potential to give an insight view of genetic diversity and facilitate to understand the local, global and regional expansion whether through multiple molecular relationships between plasmids or due to any one single dominant plasmid type (Das and Mandal 2019). A genomic study indicated the prevalence of a single plasmid in Shigella, facilitated by horizontal gene transfer found to be as major culprit in the emergence of existing and new epidemics (Baker et al. 2018b). Another study further affirms that the global expansion of $S$. sonneiresistant strains was due to a single clone. The study showed that resistance to fluoroquinolone is due to sequential mutations (gyrA-S83L, parC-S80I, and gyrA-D87G) in S. sonnei from South Asia around 2007, prior to its distribution in Southeast Asia and Europe. Furthermore, the mutational analysis showed that the clone has a strong adaptiveness towards the oxidative stress that probably reflect its dominance pattern (Chung The et al. 2019).

Therefore, a significant relation exists between the Integron (class II) and developing of resistance towards the different kinds of antimicrobials in S. sonnei (Gassama-Sow et al. 2006). The gain of class II integrons by S. sonnei and substantial mutational changes create selective pressure on antibiotics, thus resulting in the emergence of resistant strains.

\section{Prevention and controlling strategies}

Antibiotics are the best sources to deal with S. sonnei infection, having low cost with community-accessible approach. But, due to emergence of resistance, it is very important to use antibiotics rationally with appropriate prescription. The AMR issue, has significant impacts on the ecology and society, as rising of the combined social cost of AMR from the individual cost of antibiotics (Okeke et al. 2007). The implementation of WASH measures gain significance and exhibit supreme importance, where Shigella spp. and other enteric pathogens evolve and emerge. "One Health" approach is an ideal way of carefully monitoring the origin, sources of possible transmission and routes in environment, human and animal triad (Heymann et al. 2017). This one health approach works in collaboration among the various disciplines of sciences with multisectoral organization locally, regionally, and globally in the better survival and nourishment of civil society (Kahn 2017; Nadimpalli et al. 2018). The safe and widespread effective vaccines are also welcoming alternative approach to antibiotics and hence will dampen the issue of AMR. Therefore, a continuous endeavour and investment is needed to control and limit the S. son$n e i$ infection and shifting spectrum.

\section{Future perspective}

There is a lot more work needed to explore further about the S. sonnei. As some studies has unfold the several aspects of its pathogenesis and virulence mechanisms, but still lies a gap between its actual origin among Shigella spp. The shifting pattern of $S$. sonnei from developed to developing countries still need attention and demands explanation. There might be the existence of other special systems along with T3SS and T6SS. The structural and molecular area of $S$. sonnei needed to be under consideration for the discovery of complex underlying mechanisms. The $S$. sonnei epidemiology in relation with other closely related species needed appropriate surveillance and monitoring, in order of understanding the global risen burden and changing landscape. The IpaB and IpaD protein of $S$. sonnei has been indicated as a potential safe and sound candidate for the vaccine development in a clinical testing against mice (Martinez-Becerra 
et al. 2012; Heine et al. 2014, 2015). In recent times, due to advancement of technology, new lab tools, equipment's, protocols and reducing cost of sequencing, the responsibility of healthcare workers and scientists rises than ever to look for better options and developing strategies for the service of mankind.

\section{Conclusion}

Shigella has been considered as a priority pathogen by WHO recently, the uniqueness in the structure, pathogenesis and virulence mechanisms stand out Shigella. More recently, the global changing landscape and shifting pattern of species from $S$. flexneri to $S$. sonnei has urged the attention to seek behind the mysterious ongoing pathways. The different sources and routes of transmission, epidemiological variations in relation to anthropogenic activities like travelling and trade has raised many questions regarding the dispersion of $S$. sonnei single clone. Additionally, the growing AMR burden of $S$. sonnei has worsen the therapeutic options as no drug can be considered as standard option. The growing resistance to antimicrobials and the stagnancy in developing of new antibiotics is a horrible scenario. Therefore, rational use of antibiotics, vaccines development, adapting appropriate WASH measures, and meanwhile having eye on the genomic and epidemiological patterns of S. sonnei can only dampen the growing problem and tackle this emerging pathogen.

\section{Compliance with ethical standards}

Conflict of interest None to declare.

\section{References}

Ahmed AM, Furuta K, Shimomura K, Kasama Y, Shimamoto T (2006) Genetic characterization of multidrug resistance in Shigella spp. from Japan. J Med Microbiol 55(12):1685-1691. https://doi. org/10.1099/jmm.0.46725-0

Al-Dahmoshi HOM, Al-Khafaji NSK, Al-Allak MH, Salman WK, Alabbasi AH (2020) A review on shigellosis: pathogenesis and antibiotic resistance. Drug Invent Today 14:793-798

Anandan S, Sethuvel DPM, Gajendiren R, Verghese VP, Walia K, Veeraraghavan B (2017) Molecular characterization of antimicrobial resistance in clinical Shigella isolates during 2014 and 2015: Trends in South India. Germs 7(3):115. https://doi.org/10.18683 /germs.2017.1116

Anderson M, Sansonetti PJ, Marteyn BS (2016) Shigella diversity and changing landscape: insights for the twenty-first century. Front Cell Infect Microbiol 6:45

Anderson MC, Vonaesch P, Saffarian A, Marteyn BS, Sansonetti PJ (2017) Shigella sonnei encodes a functional T6SS used for interbacterial competition and niche occupancy. Cell Host Microbe 21(6):769-776. https://doi.org/10.1016/j.chom.2017.05.004
Ashida H, Ogawa M, Mimuro H, Kobayashi T, Sanada T, Sasakawa C (2011) Shigella are versatile mucosal pathogens that circumvent the host innate immune system. Curr Opin Immunol 23(4):448-455

Ashida H, Mimuro H, Sasakawa C (2015) Shigella manipulates host immune responses by delivering effector proteins with specific roles. Front Immunol 6:219

Ashkenazi S (2004) Shigella infections in children: new insights. Semin Pediatr Infect Dis 15:246-252. https://doi.org/10.1053/j. spid.2004.07.005

Ashkenazi S, Cohen D (2013) An update on vaccines against Shigella. Ther Adv Vaccines 1(3):113-123. https://doi. org/10.1177/2051013613500428

Auda IG (2014) Occurrence of CTX-M-I and CTX-M-III genes on plasmids of Shigella species isolated from cases of diarrhea in Baghdad. World J Pharm Res 3:1273-1280

Babaei S, Bajelani F, Mansourizaveleh O, Abbasi A, Oubari F (2017) A study of the bactericidal effect of copper oxide nanoparticles on Shigella sonnei and salmonella typhimurium. J Babol Univ Med Sci 19(11):76-81. https://doi.org/10.18869/acadp ub.jbums.19.11.76

Baker S, The HC (2018) Recent insights into Shigella: a major contributor to the global diarrhoeal disease burden. Curr Opin Infect Dis 31(5):449

Baker KS, Dallman TJ, Ashton PM, Day M, Hughes G, Crook PD, Gilbart VL, Zittermann S, Allen VG, Howden BP, Tomita T, Valcanis M, Harris SR, Connor TR, Sintchenko V, Howard P, Brown JD, Petty NK, Gouali M, Thanh DP, Keddy KH, Smith AM, Talukder KA, Faruque SM, Parkhill J, Baker S, Weill FX, Jenkins C, Thomson NR (2015) Intercontinental dissemination of azithromycin-resistant shigellosis through sexual transmission: a cross-sectional study. Lancet Infect Dis 15(8):913-921. https://doi.org/10.1016/S1473-3099(15)00002-X

Baker KS, Dallman TJ, Behar A, Weill FX, Gouali M, Sobel J, Fookes M, Valinsky L, Gal-Mor O, Connor TR, Nissan I, Bertrand S, Parkhill J, Jenkins C, Cohen D, Thomson NR (2016) Travel- and community-based transmission of multidrugresistant Shigella sonnei lineage among international Orthodox Jewish communities. Emerg Infect Dis 22(9):1545. https://doi. org/10.3201/eid2209.151953

Baker KS, Dallman TJ, Field N, Childs T, Mitchell H, Day M, Weill FX, Lefèvre S, Tourdjman M, Hughes G, Jenkins C, Thomson N (2018a) Genomic epidemiology of Shigella in the United Kingdom shows transmission of pathogen sublineages and determinants of antimicrobial resistance. Sci Rep 8(1):1-8. https://doi.org/10.1038/s41598-018-25764-3

Baker KS, Dallman TJ, Field N, Childs T, Mitchell H, Day M, Weill FX, Lefèvre S, Tourdjman M, Hughes G, Jenkins C, Thomson $\mathrm{N}$ (2018b) Horizontal antimicrobial resistance transfer drives epidemics of multiple Shigella species. Nat Commun 9(1):110. https://doi.org/10.1038/s41467-018-03949-8

Donald G, Barceloux MD, FAACT, FACMT F (2008) Shigella Species (Shiga Enterotoxins). Med Toxicol Nat Subst 150-155. https://doi.org/10.1002/9780470330319.ch20

Barnoy S, Jeong KI, Helm RF, Suvarnapunya AE, Ranallo RT, Tzipori S, Venkatesan MM (2010) Characterization of WRSs2 and WRSs3, new second-generation virG(icsA)-based Shigella sonnei vaccine candidates with the potential for reduced reactogenicity. Vaccine 28(6):1642-1654. https://doi.org/10.1016/j. vaccine.2009.11.001

Basu S, Paul DK, Ganguly S, Chatterjee M, Chandra PK (2009) Efficacy of high-dose Lactobacillus rhamnosus GG in controlling acute watery diarrhea in Indian children: a randomized controlled trial. J Clin Gastroenterol 43(3):208-213. https:// doi.org/10.1097/MCG.0b013e31815a5780 
Bergsbaken T, Fink SL, Cookson BT (2009) Pyroptosis: host cell death and inflammation. Nat Rev Microbiol 7(2):99-109

Bhattacharya D, Bhattacharjee H, Thamizhmani R, Sayi DS, Bharadwaj AP, Singhania M, Sugunan AP, Roy S (2011) Prevalence of the plasmid-mediated quinolone resistance determinants among clinical isolates of Shigella sp in Andaman \& Nicobar Islands India. Lett. Appl. Microbiol 53(2):247-251

Bliven K, Lampel KA (2017) Chapter 6 - Shigella. In: Dodd CER, Aldsworth T, Stein RA, Cliver DO, Riemann HPBT-FD (eds). Foodborne diseases, 3rd ed. Academic Press, pp 171-188. https://doi.org/10.1016/B978-0-12-385007-2.00006-1

Bridle H (2013) Waterborne pathogens. Detection methods and applications book. Academic Press. Elsevier ISBN:978-0444-59543-0. https://www.elsevier.com/books/waterborne -pathogens/bridle/978-0-444-59543-0

Brotcke Zumsteg A, Goosmann C, Brinkmann V, Morona R, Zychlinsky A (2014) IcsA is a Shigella flexneri adhesion regulated by the type III secretion system and required for pathogenesis. Cell Host Microbe. https://doi.org/10.1016/j.chom.2014.03.001

Brown JD, Willcox SJ, Franklin N, Hazelton B, Howard P, Reinten T, Sheppeard V, O'Sullivan M (2017) Shigella species epidemiology and antimicrobial susceptibility: the implications of emerging azithromycin resistance for guiding treatment, guidelines and breakpoints. J Antimicrob Chemother 72(11):31813186. https://doi.org/10.1093/jac/dkx268

Byarugaba DK (2004) Antimicrobial resistance in developing countries and responsible risk factors. Int $\mathbf{J}$ Antimicrob Agents 24(2):105-110

Caboni M, Pédron T, Rossi O, Goulding D, Pickard D, Citiulo F, MacLennan CA, Dougan G, Thomson NR, Saul A, Sansonetti PJ, Gerke C (2015) An O Antigen capsule modulates bacterial pathogenesis in Shigella sonnei. PLoS Pathog 11(3):e1004749. https://doi.org/10.1371/journal.ppat.1004749

Calcuttawala F, Hariharan C, Pazhani GP, Ghosh S, Ramamurthy $\mathrm{T}$ (2015) Activity spectrum of colicins produced by Shigella sonnei and genetic mechanism of colicin resistance in conspecific $S$ sonnei strains and escherichia coli. Antimicrob Agents Chemother 59(1):152-158. https://doi.org/10.1128/ AAC.04122-14

Cantón R, González-Alba JM, Galán JC (2012) CTX-M enzymes: origin and diffusion. Front Microbiol 3:110

Carayol N, Van Nhieu GT (2013) The inside story of shigella invasion of intestinal epithelial cells. Cold Spring Harb Perspect Med 3(10):a016717. https://doi.org/10.1101/cshperspect.a016717

Chang Z, Zhang J, Ran L, Sun J, Liu F, Luo L, Zeng L, Wang L, Li Z, Yu H, Liao Q (2016) The changing epidemiology of bacillary dysentery and characteristics of antimicrobial resistance of Shigella isolated in China from 2004-2014. BMC Infect Dis 16(1):685. https://doi.org/10.1186/s12879-016-1977-1

Chatterjee S, Raval IH (2019) Pathogenic microbial genetic diversity with reference to health. In: Microbial Diversity in the genomic era. Academic Press, pp. 559-577). https://doi.org/10.1016/ B978-0-12-814849-5.00032-0

Chompook P, Todd J, Wheeler JG, von Seidlein L, Clemens J, Chaicumpa W (2006) Risk factors for shigellosis in Thailand. Int J Infect Dis 10(6):425-433. https://doi.org/10.1016/j. ijid.2006.05.011

Christopher PR, David KV, John SM, Sankarapandian V (2010) Antibiotic therapy for Shigella dysentery. Cochrane Database Syst Rev 8:CD006784. https://doi.org/10.1002/14651858.cd006784.pub4

Chung The H, Rabaa MA, Pham Thanh D, De Lappe N, Cormican M, Valcanis M, Howden BP, Wangchuk S, Bodhidatta L, Mason CJ, Nguyen Thi Nguyen T, Vu Thuy D, Thompson CN, Phu Huong Lan N, Voong Vinh P, Ha Thanh T, Turner P, Sar P, Thwaites G, Thomson NR, Holt KE, Baker S (2016) South Asia as a reservoir for the global spread of ciprofloxacin-resistant Shigella sonnei: a cross-sectional study. PLoS Med 13(8):e1002055. https://doi. org/10.1371/journal.pmed.1002055

Chung The H, Boinett C, Pham Thanh D, Jenkins C, Weill FX, Howden BP, Valcanis M, De Lappe N, Cormican M, Wangchuk S, Bodhidatta L, Mason CJ, Nguyen TNT, Ha Thanh T, Voong VP, Duong VT, Nguyen PHL, Turner P, Wick R, Ceyssens PJ, Thwaites G, Holt KE, Thomson NR, Rabaa MA, Baker S (2019) Dissecting the molecular evolution of fluoroquinolone-resistant Shigella sonnei. Nat Commun 10(1):1-13. https://doi.org/10.1038/s4146 7-019-12823-0

Cohen D, Ashkenazi S, Green MS, Gdalevich M, Robin G, Slepon R, Yavzori M, Orr N, Block C, Ashkenazi I, Shemer J, Taylor DN, Hale TL, Sadoff JC, Pavliakova D, Schneerson R, Robbins JB (1997) Double-blind vaccine-controlled randomised efficacy trial of an investigational Shigella sonnei conjugate vaccine in young adults. Lancet 349(9046):155-159. https://doi.org/10.1016/ S0140-6736(96)06255-1

Dallman TJ, Chattaway MA, Mook P, Godbole G, Crook PD, Jenkins C (2016) Use of whole-genome sequencing for the public health surveillance of Shigella sonnei in England and wales, 2015. J Med Microbiol 65(8):882-884

Das A, Mandal J (2019) Extensive inter-strain diversity among clinical isolates of Shigella flexneri with reference to its serotype, virulence traits and plasmid incompatibility types, a study from south India over a 6-year period. Gut Pathog 11(1):33. https:// doi.org/10.1186/s13099-019-0314-9

De Lappe N, O’Connor J, Garvey P, McKeown P, Cormican M (2015) Ciprofloxacin-resistant Shigella sonnei associated with travel to India. Emerg Infect Dis 21(5):894

Delgado R, Otero JR (1988) High-level resistance to trimethoprim in Shigella sonnei associated with plasmid-encoded dihydrolate reductase type I. Antimicrob Agents Chemother 32(10):15981599. https://doi.org/10.1128/AAC.32.10.1598

Deutsch-Nagy L, Urbán P, Tóth Z, Bihari Z, Kocsis B, Fekete C, Kilár F (2018) Genome sequence of Shigella sonnei 4303. Gut Pathog 10(1):47. https://doi.org/10.1186/s13099-018-0274-5

Dorman CJ, Porter ME (1998) The Shigella virulence gene regulatory cascade: a paradigm of bacterial gene control mechanisms. Mol Microbiol 29(3):677-684

Du J, Reeves AZ, Klein JA, Twedt DJ, Knodler LA, Lesser CF (2016) The type III secretion system apparatus determines the intracellular niche of bacterial pathogens. Proc Natl Acad Sci 113(17):4794-4799. https://doi.org/10.1073/pnas.1520699113

DuPont HL (2014) Acute infectious diarrhea in immunocompetent adults. N Engl J Med 370(16):1532-1540

Faherty CS, Redman JC, Rasko DA, Barry EM, Nataro JP (2012) Shigella flexneri effectors OspE1 and OspE2 mediate induced adherence to the colonic epithelium following bile salts exposure. Mol Microbiol 85(1):107-121. https://doi.org/10.111 $1 / \mathrm{j} .1365-2958.2012 .08092 . \mathrm{x}$

Fang FC, Patel R (2017) 2017 infectious diseases society of america infectious diarrhea guidelines: a view from the clinical laboratory. Clin Infect Dis 65(12):1974-1976. https://doi.org/10.1093/ cid/cix730

García-Fulgueiras A, Sánchez S, Guillén JJ, Marsilla B, Aladueña A, Navarro C (2001) A large outbreak of Shigella sonnei gastroenteritis associated with consumption of fresh pasteurised milk cheese. Eur J Epidemiol 17(6):533-538. https://doi. org/10.1023/A:1014504305666

Gassama-Sow A, Diallo MH, Boye CS, Garin B, Sire JM, Sow AI, Aïdara-Kane A (2006) Class 2 integron-associated antibiotic resistance in Shigella sonnei isolates in Dakar. Senegal Int J Antimicrob Agents 27(3):267-270. https://doi.org/10.1016/j. ijantimicag.2005.10.016

Gaynor K, Park SY, Kanenaka R, Colindres R, Mintz E, Ram PK, Kitsutani P, Nakata M, Wedel S, Boxrud D, Jennings D, Yoshida 
H, Tosaka N, He H, Ching-Lee M, Effler PV (2009) International foodborne outbreak of Shigella sonnei infection in airline passengers. Epidemiol Infect 137(3):335-341. https://doi.org/10.1017/ S0950268807000064

Gentle A, Ashton PM, Dallman TJ, Jenkins C (2016) Evaluation of molecular methods for serotyping shigella flexneri. J Clin Microbiol 54(6):1456-1461. https://doi.org/10.1128/JCM.03386-15

Gonzalez MD, McElvania E (2018) New developments in rapid diagnostic testing for children. Infect Dis Clin 32(1):19-34

Gu B, Cao Y, Pan S, Zhuang L, Yu R, Peng Z, Qian H, Wei Y, Zhao L, Liu G, Tong M (2012) Comparison of the prevalence and changing resistance to nalidixic acid and ciprofloxacin of Shigella between Europe-America and Asia-Africa from 1998 to 2009. Int J Antimicrob Agents 40(1):9-17

Gu B, Zhou M, Ke X, Pan S, Cao Y, Huang Y, Zhuang L, Liu G, Tong M (2015) Comparison of resistance to third-generation cephalosporins in Shigella between Europe-America and Asia-Africa from 1998 to 2012. Epidemiol Infect 143(13):2687-2699

Gu B, T-ting Q, W-ting F, R-ru Bi, Chen Y, Li Y, Ma P (2017) Novel mutations in gyrA and parC among Shigella sonnei strains from Jiangsu Province of China, 2002-2011. Int J Infect Dis 59:44-49. https://doi.org/10.1016/j.ijid.2017.03.023

Gupta AK, Nayduch D, Verma P, Shah B, Ghate HV, Patole MS, Shouche YS (2012) Phylogenetic characterization of bacteria in the gut of house flies (Musca domestica L.). FEMS Microbiol Ecol 79(3):581-593. https://doi.org/10.111 1/j.1574-6941.2011.01248.x

Hannu T, Mattila L, Siitonen A, Leirisalo-Repo M (2005) Reactive arthritis attributable to Shigella infection: a clinical and epidemiological nationwide study. Ann Rheum Dis 64(4):594-598. https://doi.org/10.1136/ard.2004.027524

Hao Y, Liao W, Ma W, Zhang J, Zhang N, Zhong S, Wang Z, Yang L, Huang C (2019) Effects of ambient temperature on bacillary dysentery: a multi-city analysis in Anhui Province, China. Sci Total Environ 671:1206-1213. https://doi.org/10.1016/j.scito tenv.2019.03.443

Hayward RD, Cain RJ, McGhie EJ, Phillips N, Garner MJ, Koronakis V (2005) Cholesterol binding by the bacterial type III translocon is essential for virulence effector delivery into mammalian cells. Mol Microbiol 56(3):590-603. https://doi.org/10.111 1/j.1365-2958.2005.04568.x

Heine SJ, Diaz-McNair J, Andar AU, Drachenberg CB, van de Verg L, Walker R, Picking WL, Pasetti MF (2014) Intradermal delivery of Shigella IpaB and IpaD type III secretion proteins: kinetics of cell recruitment and antigen uptake, mucosal and systemic immunity, and protection across serotypes. J Immunol 192(4):1630-1640. https://doi.org/10.4049/jimmunol.1302743

Heine SJ, Franco-Mahecha OL, Chen X, Choudhari S, Blackwelder WC, Van Roosmalen ML, Leenhouts K, Picking WL, Pasetti MF (2015) Shigella IpaB and IpaD displayed on L. lactis bacteriumlike particles induce protective immunity in adult and infant mice. Immunol Cell Biol 93(7):641-652. https://doi.org/10.1038/ icb.2015.24

Heymann DL, Jay J, Kock R (2017) The one health path to infectious disease prevention and resilience. Trans R Soc Trop Med Hyg 111(6):233-234

Holt KE, Baker S, Weill FX, Holmes EC, Kitchen A, Yu J, Sangal V, Brown DJ, Coia JE, Kim DW, Choi SY, Kim SH, Da Silveira WD, Pickard DJ, Farrar JJ, Parkhill J, Dougan G, Thomson NR (2012) Shigella sonnei genome sequencing and phylogenetic analysis indicate recent global dissemination from Europe. Nat Genet 44(9):1056-1059. https://doi.org/10.1038/ng.2369

Husby S, Koletzko S, Korponay-Szabó IR, Mearin ML, Phillips A, Shamir R, Troncone R, Giersiepen K, Branski D, Catassi C, Lelgeman M, Mäki M, Ribes-Koninckx C, Ventura A, Zimmer KP (2012) European society for pediatric gastroenterology, hepatology, and nutrition guidelines for the diagnosis of coeliac disease. J Pediatr Gastroenterol Nutr 54(1):136-160

Ingle DJ, Easton M, Valcanis M, Seemann T, Kwong JC, Stephens N, Carter GP, Gonçalves Da Silva A, Adamopoulos J, Baines SL, Holt KE, Chow EPF, Fairley CK, Chen MY, Kirk MD, Howden BP, Williamson DA (2019) Co-circulation of Multidrug-resistant Shigella among Men Who Have Sex with Men in Australia. Clin Infect Dis 69(9):1535-1544. https://doi. org/10.1093/cid/ciz005

Jamal M, Chaudhry WN, Hussain T, Das CR, Andleeb S (2015) Characterization of new Myoviridae bacteriophage WZ1 against multi-drug resistant (MDR) Shigella dysenteriae. J Basic Microbiol 55(4):420-431. https://doi.org/10.1002/jobm.201400688

Johnson DI (2017) Bacterial pathogens and their virulence factors. Springer, Cham

Johnson AP, Woodford N (2013) Global spread of antibiotic resistance: the example of New Delhi metallo- $\beta$-lactamase (NDM)-mediated carbapenem resistance. J Med Microbiol 62(4):499-513

Kahn LH (2017) Antimicrobial resistance: a One Health perspective. Trans R Soc Trop Med Hyg 111(6):255-260

Kahsay AG, Muthupandian S (2016) A review on Sero diversity and antimicrobial resistance patterns of Shigella species in Africa, Asia and South America, 2001-2014. BMC Res Notes 9(1):422

Kaminski RW, Oaks EV (2009) Inactivated and subunit vaccines to prevent shigellosis. Expert Rev Vaccines 8(12):1693-1704

Khalil IA, Troeger C, Blacker BF, Rao PC, Brown A, Atherly DE, Brewer TG, Engmann CM, Houpt ER, Kang G, Kotloff KL, Levine MM, Luby SP, MacLennan CA, Pan WK, Pavlinac PB, PlattsMills JA, Qadri F, Riddle MS, Ryan ET, Shoultz DA, Steele AD, Walson JL, Sanders JW, Mokdad AH, Murray CJL, Hay SI, Reiner RC (2018) Morbidity and mortality due to shigella and enterotoxigenic Escherichia coli diarrhoea: the Global Burden of Disease Study 1990-2016. Lancet Infect Dis 18(11):1229-1240. https://doi.org/10.1016/S1473-3099(18)30475-4

Killackey SA, Sorbara MT, Girardin SE (2016) Cellular aspects of Shigella pathogenesis: focus on the manipulation of host cell processes. Front Cell Infect Microbiol 6:38

Kimberlin DW, Brady MT, Jackson MA, Long SS (2015) Shigella infections. Red Book: 2015 Report of the Committee on Infectious Diseases, 30th Edition. Elk Grove Village. American Academy of Pediatrics, IL, 706. https://ebooks.aappublications.org/ content/red-book-30th-edition-2015

Kimura AC, Johnson K, Palumbo MS, Hopkins J, Boase JC, Reporter R, Goldoft M, Stefonek KR, Farrar JA, Van Gilder TJ, Vugia DJ (2004) Multistate shigellosis outbreak and commercially prepared food United States. Emerg Infect Dis 10(6):1147. https:// doi.org/10.3201/eid1006.030599

Ko CF, Lin NT, Chiou CS, Wang LY, Liu MC, Yang CY, Lee YS (2013) Infrequent cross-transmission of Shigella flexneri 2a strains among villages of a mountainous township in Taiwan with endemic shigellosis. BMC Infect Dis 13(1):354. https://doi. org/10.1186/1471-2334-13-354

Kotloff KL, Riddle MS, Platts-Mills JA, Pavlinac P, Zaidi AKM (2018) Shigellosis. Lancet 391(10122):801-812

Kozyreva VK, Jospin G, Greninger AL, Watt JP, Eisen JA, Chaturvedi V (2016) Recent outbreaks of Shigellosis in California caused by two Distinct Populations of Shigella sonnei with either increased virulence or fluoroquinolone resistance. mSphere. https://doi. org/10.1128/msphere.00344-16

Kuo HW, Kasper S, Jelovcan S, Höger G, Lederer I, König C, Pridnig G, Luckner-Hornischer A, Allerberger F, Schmid D (2009) A food-borne outbreak of Shigella sonnei gastroenteritis, Austria, 2008. Wien Klin Wochenschr 121(3-4):157-163. https://doi. org/10.1007/s00508-008-1141-7

Lampel K (2012) Bad bug book: handbook of foodborne pathogenic microorganisms and natural toxins. US Food and Drug 
Administration, Silver Spring. https://doi.org/10.1016/S1872 -2040(10)60451-3

Lampel KA, Formal SB, Maurelli AT (2018) A brief history of Shigella. EcoSal Plus. https://doi.org/10.1128/ecosalplus .esp-0006-2017

Lee LA, Ostroff SM, Mcgee HB, Johnson DR, Downes FP, Cameron DN, Bean NH, Griffin PM (1991) An outbreak of shigellosis at an outdoor music festival. Am J Epidemiol 133(6):608-615. https ://doi.org/10.1093/oxfordjournals.aje.a115933

Lee TM, Chang CY, Chang LL, Chen WM, Wang TK, Chang SF (2003) One predominant type of genetically closely related Shigella sonnei prevalent in four sequential outbreaks in school children. Diagn Microbiol Infect Dis 45(3):173-181. https://doi. org/10.1016/S0732-8893(02)00524-2

Levine MM, Kotloff KL, Barry EM, Pasetti MF, Sztein MB (2007) Clinical trials of Shigella vaccines: two steps forward and one step back on a long, hard road. Nat Rev Microbiol 5(7):540-553

Lewis HC, Ethelberg S, Olsen KEP, Nielsen EM, Lisby M, Madsen SB, Boel J, Stafford R, Kirk M, Smith HV, Tikumrum S, Wisetrojana A, Bangtrakulnonth A, Vithayarungruangsri J, Siriarayaporn P, Ungchusak K, Bishop J, Mølbak K (2009) Outbreaks of Shigella sonnei infections in Denmark and Australia linked to consumption of imported raw baby corn. Epidemiol Infect 137(3):326-334

Liao YS, Liu YY, Lo YC, Chiou CS (2017) Azithromycin-nonsusceptible Shigella flexneri $3 \mathrm{a}$ in men who have sex with men, Taiwan, 2015-2016. Emerg Infect Dis 23(2):345

Liu B, Knirel YA, Feng L, Perepelov AV, Senchenkova SN, Wang Q, Reeves PR, Wang L (2008) Structure and genetics of Shigella O antigens. FEMS Microbiol Rev 32(4):627-653

Livio S, Strockbine NA, Panchalingam S, Tennant SM, Barry EM, Marohn ME, Antonio M, Hossain A, Mandomando I, Ochieng JB, Oundo JO, Qureshi S, Ramamurthy T, Tamboura B, Adegbola RA, Hossain MJ, Saha D, Sen S, Faruque ASG, Alonso PL, Breiman RF, Zaidi AKM, Sur D, Sow SO, Berkeley LY, O'Reilly CE, Mintz ED, Biswas K, Cohen D, Farag TH, Nasrin D, Wu Y, Blackwelder WC, Kotloff KL, Nataro JP, Levine MM (2014) Shigella isolates from the global enteric multicenter study inform vaccine development. Clin Infect Dis 59(7):933-941. https://doi. org/10.1093/cid/ciu468

Mahmoud RY, Stones DH, Li W, Emara M, El-domany RA, Wang D, Wang Y, Krachler AM, Yu J (2016) The multivalent adhesion molecule SSO1327 plays a key role in Shigella sonnei pathogenesis. Mol Microbiol 99(4):658-673. https://doi.org/10.1111/ mmi. 13255

Maldonado-Contreras A, Birtley JR, Boll E, Zhao Y, Mumy KL, Toscano J, Ayehunie S, Reinecker HC, Stern LJ, McCormick BA (2017) Shigella depends on SepA to destabilize the intestinal epithelial integrity via cofilin activation. Gut Microbes 8(6):544560. https://doi.org/10.1080/19490976.2017.1339006

Martinez-Becerra FJ, Kissmann JM, Diaz-Mcnair J, Choudhari SP, Quick AM, Mellado-Sanchez G, Clements JD, Pasetti MF, Picking WL (2012) Broadly protective Shigella vaccine based on type III secretion apparatus proteins. Infect Immun 80(3):1222-1231. https://doi.org/10.1128/IAI.06174-11

Mathipa MG, Thantsha MS (2017) Probiotic engineering: towards development of robust probiotic strains with enhanced functional properties and for targeted control of enteric pathogens. Gut Pathog 9(1):28

Mattock E, Blocker AJ (2017) How do the virulence factors of shigella work together to cause disease? Front Cell Infect Microbiol 7:64. https://doi.org/10.3389/fcimb.2017.00064

McDonnell J, Dallman T, Atkin S, Turbitt DA, Connor TR, Grant KA, Thomson NR, Jenkins C (2013) Retrospective analysis of whole genome sequencing compared to prospective typing data in further informing the epidemiological investigation of an outbreak of Shigella sonnei in the UK. Epidemiol Infect 141(12):2568-2575. https://doi.org/10.1017/S095026881 3000137

Mellouk N, Enninga J (2016) Cytosolic access of intracellular bacterial pathogens: the Shigella paradigm. Front Cell Infect Microbiol 6:35

Mook P, McCormick J, Bains M, Cowley LA, Chattaway MA, Jenkins C, Mikhail A, Hughes G, Elson R, Day M, Manuel R, Dave J, Field N, Godbole G, Dallman T, Crook P (2016) ESBL-Producing and macrolide-resistant Shigella sonnei infections among men who have sex with men, England, 2015. Emerg Infect Dis 22(11):1948. https://doi.org/10.3201/eid2211.160653

Morgan O, Crook P, Cheasty T, Jiggle B, Giraudon I, Hughes H, Jones SM, Maguire H (2006) Shigella sonnei outbreak among homosexual men. London Emerg Infect Dis 12:1458-1460

Muller L, Jensen T, Petersen RF, Mølbak K, Ethelberg S (2009) Imported fresh sugar peas as suspected source of an outbreak of Shigella sonnei in Denmark, April-May 2009. Euro Surveill 14(24):19241. https://doi.org/10.2807/ese.14.24.19241-en

Muthuirulandi Sethuvel DP, Devanga Ragupathi NK, Anandan S, Veeraraghavan B (2017) Update on: Shigella new serogroups/ serotypes and their antimicrobial resistance. Lett Appl Microbiol 64(1):8-18

Nadimpalli M, Delarocque-Astagneau E, Love DC, Price LB, Huynh BT, Collard JM, Lay KS, Borand L, Ndir A, Walsh TR, Guillemot D, De Lauzanne A, Kerleguer A, Tarantola A, Piola P, Chon T, Lach S, Ngo V, Touch S, Andrianirina ZZ, Vray M, Richard V, Seck A, Bercion R, Sow AG, Diouf JB, Dieye PS, Sy B, Ndao B, Seguy M, Watier L, Abdou AY (2018) Combating global antibiotic resistance: emerging one health concerns in lower-and middle-income Countries. Clin Infect Dis 66(6):963-969. https ://doi.org/10.1093/cid/cix879

Naimi TS, Wicklund JH, Olsen SJ, Krause G, Wells JG, Bartkus JM, Boxrud DJ, Sullivan M, Kassenborg H, Besser JM, Mintz ED, Osterholm MT, Hedberg CW (2003) Concurrent outbreaks of Shigella sonnei and enterotoxigenic Escherichia coli infections associated with parsley: implications for surveillance and control of foodborne illness. J Food Prot 66(4):535-541. https://doi. org/10.4315/0362-028X-66.4.535

Nicolò MS, Gioffrè A, Carnazza S, Platania G, Di SI, Guglielmino SPP (2011) Viable but nonculturable state of foodborne pathogens in grapefruit juice: a study of laboratory. Foodborne Pathog Dis 8(1):11-17. https://doi.org/10.1089/fpd.2009.0491

Nisa I, Qasim M, Yasin N, Ullah R, Ali A (2020) Shigella flexneri: an emerging pathogen. Folia Microbiol 65:275-291

Nisar M, Ahmed M-D, Hassan Mushtaq M, Akbar Khan S, Hussain A, Asad Ali M, Abbas M, Mohsin Khan M, Tehseen Khan M (2014) Clinico-epidemiology of shigellosis in children suffering from Diarrhea in District Lahore, Pakistan. Int J Curr Microbiol App Sci 3:950-957

Niyogi SK (2005) Shigellosis. J Microbiol (Seoul, Korea) 43(2):133

Nyanga PL, Onyuka J, Webale MK, Were T, Budambula V (2017) Escherichia coli pathotypes and Shigella sero-groups in diarrheic children in Nairobi city, Kenya. Gastroenterol Hepatol from Bed to Bench 10(3):220. https://doi.org/10.22037/ghfbb.v0i0.1076

Nygren BL, Schilling KA, Blanton EM, Silk BJ, Cole DJ, Mintz ED (2013) Foodborne outbreaks of shigellosis in the USA, 19982008. Epidemiol Infect 141(2):233-241. https://doi.org/10.1017/ S0950268812000222

Okeke IN, Aboderin OA, Byarugaba DK, Ojo KK, Opintan JA (2007) Growing problem of multidrug-resistant enteric pathogens in Africa. Emerg Infect Dis 13(11): 1640

OzFoodNet Working Group (2012) Monitoring the incidence and causes of diseases potentially transmitted by food in Australia: annual report of the OzFoodNet network, 2010. Commun Dis Intell 42:S2209-6051 
Pai H (2020) History and epidemiology of bacillary dysentery in Korea: from Korean war to 2017. Infect Chemother 52(1):123131. https://doi.org/10.3947/ic.2020.52.1.123

Pazhani GP, Niyogi SK, Singh AK, Sen B, Taneja N, Kundu M, Yamasaki S, Ramamurthy T (2008) Molecular characterization of multidrug-resistant Shigella species isolated from epidemic and endemic cases of shigellosis in India. J Med Microbiol 57(7):856-863. https://doi.org/10.1099/jmm.0.2008/000521-0

Peirano G, Agers $\varnothing$ Y, Aarestrup FM, dos Prazeres RD (2005) Occurrence of integrons and resistance genes among sulphonamideresistant Shigella spp. from Brazil. J Antimicrob Chemother 55(3):301-305. https://doi.org/10.1093/jac/dki012

Phalipon A, Sansonetti PJ (2007) Shigella's ways of manipulating the host intestinal innate and adaptive immune system: a tool box for survival? Immunol Cell Biol 85(2):119-129

Porter CK, Olson S, Hall A, Riddle MS (2017) Travelers' diarrhea: an update on the incidence, etiology, and risk in military deployments and similar travel populations. Mil Med 182:4-10. https ://doi.org/10.7205/milmed-d-17-00064

Pupo GM, Lan R, Reeves PR (2000) Multiple independent origins of Shigella clones of Escherichia coli and convergent evolution of many of their characteristics. Proc Natl Acad Sci 97(19):1056710572. https://doi.org/10.1073/pnas.180094797

Qiu S, Xu X, Yang C, Wang J, Liang B, Li P, Li H, Yi S, Liu H, Cui X, Wu Z, Xie J, Jia L, Wang L, Hao R, Jin H, Wang Y, Sun Y, Song H (2015) Shift in serotype distribution of Shigella species in China, 2003-2013. Clin Microbiol Infect 21(3):252-e5. https ://doi.org/10.1016/j.cmi.2014.10.019

Ranjbar R, Farahani A (2019) Shigella: antibiotic-resistance mechanisms and new horizons for treatment. Infect Drug Resist $12: 3137$

Roehrich AD, Martinez-Argudo I, Johnson S, Blocker AJ, Veenendaal AKJ (2010) The extreme C terminus of Shigella flexneri IpaB is required for regulation of type III secretion, needle tip composition, and binding. Infect Immun 78(4):1682-1691. https://doi. org/10.1128/IAI.00645-09

Romero S, Grompone G, Carayol N, Mounier J, Guadagnini S, Prevost MC, Sansonetti PJ, Tran Van Nhieu G (2011) ATP-mediated Erk1/2 activation stimulates bacterial capture by filopodia, which precedes Shigella invasion of epithelial cells. Cell Host Microbe 9(6):508-519. https://doi.org/10.1016/j.chom.2011.05.005

Ruekit S, Wangchuk S, Dorji T, Tshering KP, Pootong P, Nobthai P, Serichantalergs O, Poramathikul K, Bodhidatta L, Mason CJ (2014) Molecular characterization and PCR-based replicon typing of multidrug resistant Shigella sonnei isolates from an outbreak in Thimphu. Bhutan BMC Res Notes 7(1):95. https://doi. org/10.1186/1756-0500-7-95

Saeed A, Abd H, Edvinsson B, Sandström G (2009) Acanthamoeba castellanii an environmental host for Shigella dysenteriae and Shigella sonnei. Arch Microbiol 191(1):83. https://doi. org/10.1007/s00203-008-0422-2

Schwarz S, Johnson AP (2016) Transferable resistance to colistin: a new but old threat. J Antimicrob Chemother 71(8):2066-2070. https://doi.org/10.1093/jac/dkw274

Shakoor S, Platts-Mills JA, Hasan R (2019) Antibiotic-resistant enteric infections. Infect Dis Clin North Am 33:1105-1123. https://doi. org/10.1016/j.idc.2019.05.007

Shepherd JG, Wang L, Reeves PR (2000) Comparison of O-antigen gene clusters of Escherichia coli (Shigella) sonnei and Plesiomonas shigelloides O17: Sonnei gained its current plasmidborne O-antigen genes from $P$. shigelloides in a Recent event. Infect Immun 68(10):6056-6061. https://doi.org/10.1128/ IAI.68.10.6056-6061.2000

Simms I, Field N, Jenkins C, Childs T, Gilbart VL, Dallman TJ, Mook P, Crook PD, Hughes G (2015) Intensified shigellosis epidemic associated with sexual transmission in men who have sex with
men-Shigella fexneri and S. Sonnei in England, 2004 to end of February 2015. Eurosurveillance 20(15):21097. https://doi. org/10.2807/1560-7917.es2015.20.15.21097

Starling S (2017) Bacterial secretion: Shigella sonnei has the edge. Nat Rev Microbiol 15:450-451. https://doi.org/10.1038/nrmic ro. 2017.74

Steffen R, Jiang ZD, Gracias Garcia ML, Araujo P, Stiess M, Nacak T, Greinwald R, DuPont HL (2018) Rifamycin SV-MMX® for treatment of travellers' diarrhea: equally effective as ciprofloxacin and not associated with the acquisition of multi-drug resistant bacteria. J Travel Med 25(1):116. https://doi.org/10.1093/ $\mathrm{jtm} / \mathrm{tay} 116$

Stensrud KF, Adam PR, La Mar CD, Olive AJ, Lushington GH, Sudharsan R, Shelton NL, Givens RS, Picking WL, Picking WD (2008) Deoxycholate interacts with IpaD of Shigella flexneri in inducing the recruitment of IpaB to the type III secretion apparatus needle tip. J Biol Chem 283(27):18646-18654. https://doi. org/10.1074/jbc.M802799200

Suzuki S, Mimuro H, Kim M, Ogawa M, Ashida H, Toyotome T, Franchi L, Suzuki M, Sanada T, Suzuki T, Tsutsui H, Núñez G, Sasakawa C, Isberg RR (2014) Shigella IpaH7.8 E3 ubiquitin ligase targets glomulin and activates inflammasomes to Demolish macrophages. Proc Natl Acad Sci 111(40):E4254-E4263. https ://doi.org/10.1073/pnas.1324021111

Sváb D, Bálint B, Vásárhelyi B, Maróti G, Tóth I (2017) Comparative genomic and phylogenetic analysis of a shiga toxin producing Shigella sonnei (STSS) strain. Front Cell Infect Microbiol 7:229. https://doi.org/10.3389/fcimb.2017.00229

Tacconelli E, Magrini N, Kahlmeter G, Singh N (2017) Global priority list of antibiotic-resistant batceria to guide research, discovery, and development of new antibiotics. World Health Organ $27: 318-327$

Taneja N, Mewara A (2016) Shigellosis: epidemiology in India. Indian J Med Res 143(5):565

Tang XJ, Yang Z, Bin CX, Tian WF, Tu CN, Wang HB (2018) Verification and large scale clinical evaluation of a national standard protocol for Salmonella spp./Shigella spp. screening using realtime PCR combined with guided culture. J Microbiol Methods 145:14-19. https://doi.org/10.1016/j.mimet.2017.12.007

Thanh DP, Thanh Tuyen H, Nguyen Thi Nguyen T, Chung The H, Wick RR, Thwaites GE, Baker S, Holt KE (2016) Inducible colistin resistance via a disrupted plasmid-borne mcr-1 gene in a 2008 Vietnamese Shigella sonnei isolate. J Antimicrob Chemother 71(8):2314-2317. https://doi.org/10.1093/jac/dkw173

The HC, Baker S (2018) Out of Asia: the independent rise and global spread of fluoroquinolone-resistant Shigella. Microb Genom 4(4). https://doi.org/10.1099/mgen.0.000171

The HC, Thanh DP, Holt KE, Thomson NR, Baker S (2016) The genomic signatures of Shigella evolution, adaptation and geographical spread. Nat Rev Microbiol 14(4):235

The World Bank (2015) World development indicators. https://data. worldbank.org/indicator/

Thiem VD, Sethabutr O, Von Seidlein L, Van Tung T, Canh DG, Chien BT, Tho LH, Lee H, Houng HS, Hale TL, Clemens JD, Mason C, Trach DD (2004) Detection of Shigella by a PCR assay targeting the ipaH gene suggests increased prevalence of Shigellosis in Nha Trang. Vietnam J Clin Microbiol 42(5):2031-2035. https:// doi.org/10.1128/JCM.42.5.2031-2035.2004

Thompson CN, Duy PT, Baker S (2015) The rising dominance of Shigella sonnei: an intercontinental shift in the etiology of bacillary dysentery. PLoS Negl Trop Dis 9(6):e0003708

Tillotson G (2018) A crucial list of pathogens. Lancet Infect Dis 18(3):234-236

Toro CS, Farfán M, Contreras I, Flores O, Navarro N, Mora GC, Prado V (2005) Genetic analysis of antibiotic-resistance determinants in multidrug-resistant Shigella strains isolated from Chilean 
children. Epidemiol Infect 133(1):81-86. https://doi.org/10.1017/ S0950268804003048

Torraca V, Kaforou M, Watson J, Duggan GM, Guerrero-Gutierrez H, Krokowski S, Hollinshead M, Clarke TB, Mostowy RJ, Tomlinson GS, Sancho-Shimizu V, Clements A, Mostowy S (2019) Shigella sonnei infection of zebrafish reveals that $\mathrm{O}$-antigen mediates neutrophil tolerance and dysentery incidence. PLoS Pathog 15(12):e1008006. https://doi.org/10.1371/journal.ppat.1008006

Torraca V, Holt K, Mostowy S (2020) Shigella sonnei. Trends Microbiol 28(8):696-697. https://doi.org/10.1016/j.tim.2020.02.011

Tribble DR (2017) Antibiotic therapy for acute watery diarrhea and dysentery. Mil Med 182:17-25. https://doi.org/10.7205/milme d-d-17-00068

Trofa AF, Ueno-Olsen H, Oiwa R, Yoshikawa M (1999) Dr. Kiyoshi Shiga: discoverer of the dysentery bacillus. Clin Infect Dis 29(5):1303-1306. https://doi.org/10.1086/313437

Ud-Din AIMS, Wahid SUH, Latif HA, Shahnaij M, Akter M, Azmi IJ, Hasan TN, Ahmed D, Hossain MA, Faruque ASG, Faruque SM, Talukder KA (2013) Changing trends in the prevalence of Shigella species: emergence of multi-drug resistant Shigella sonnei biotype g in Bangladesh. PLoS ONE 8(12):e82601. https:// doi.org/10.1371/journal.pone.0082601

Veenendaal AKJ, Hodgkinson JL, Schwarzer L, Stabat D, Zenk SF, Blocker AJ (2007) The type III secretion system needle tip complex mediates host cell sensing and translocon insertion. Mol Microbiol 63(6):1719-1730. https://doi.org/10.111 1/j.1365-2958.2007.05620.x

Wanyiri JW, Kanyi H, Maina S, Wang DE, Ngugi P, O'Connor R, Kamau T, Waithera T, Kimani G, Wamae CN, Mwamburi M, Ward HD (2013) Infectious diarrhoea in antiretroviral therapynaïve HIV/AIDS patients in Kenya. Trans R Soc Trop Med Hyg 107(10):631-638. https://doi.org/10.1093/trstmh/trt078

Watson J, Jenkins C, Clements A (2018) Shigella sonnei does not use amoebae as protective hosts. Appl Environ Microbiol 84(9):e02679-17. https://doi.org/10.1128/AEM.02679-17

Watson JL, Sanchez-Garrido J, Goddard PJ, Torraca V, Mostowy S, Shenoy AR, Clements A (2019) Shigella sonnei o-antigen inhibits internalization, vacuole escape, and inflammasome activation. MBio 10(6):e02654-19. https://doi.org/10.1128/mBio.02654-19

Wei HL, Wang YW, Li CC, Tung SK, Chiou CS (2007) Epidemiology and evolution of genotype and antimicrobial resistance of an imported Shigella sonnei clone circulating in central Taiwan. Diagn Microbiol Infect Dis 58(4):469-475. https://doi. org/10.1016/j.diagmicrobio.2007.03.006

Whitfield C (2006) Biosynthesis and assembly of capsular polysaccharides in Escherichia coli. Annu Rev Biochem 75:39-68. https:// doi.org/10.1146/annurev.biochem.75.103004.142545

Williams PCM, Berkley JA (2018) Guidelines for the treatment of dysentery (shigellosis): a systematic review of the evidence. Paediatr Int Child Health 38:S50-S65. https://doi.org/10.1080/20469 047.2017.1409454

Wu Y, Lau HK, Lee T, Lau DK, Payne J (2019) In silico serotyping based on whole-genome sequencing improves the accuracy of shigella identification. Appl Environ Microbiol 85(7):e00165-19. https://doi.org/10.1128/AEM.00165-19

Xiao G, Xu C, Wang J, Yang D, Wang L (2014) Spatial-temporal pattern and risk factor analysis of bacillary dysentery in the BeijingTianjin-Tangshan urban region of China. BMC Public Health 14(1):998. https://doi.org/10.1186/1471-2458-14-998

Yan C, Chen Y, Miao Z, Qin S, Gu H, Cai J (2018) Spatiotemporal characteristics of bacillary dysentery from 2005 to 2017 in Zhejiang Province, China. Int J Environ Res Public Health 15(9):1826. https://doi.org/10.3390/ijerph15091826

Yang F, Yang J, Zhang X, Chen L, Jiang Y, Yan Y, Tang X, Wang J, Xiong Z, Dong J, Xue Y, Zhu Y, Xu X, Sun L, Chen S, Nie H, Peng J, Xu J, Wang Y, Yuan Z, Wen Y, Yao Z, Shen Y, Qiang B, Hou Y, Yu J, Jin Q (2005) Genome dynamics and diversity of Shigella species, the etiologic agents of bacillary dysentery. Nucleic Acids Res 33(19):445-6458. https://doi.org/10.1093/ nar/gki954

Zhang Y, Zhang L, Du M, Yi H, Guo C, Tuo Y, Han X, Li J, Zhang L, Yang L (2011) Antimicrobial activity against Shigella son$n e i$ and probiotic properties of wild lactobacilli from fermented food. Microbiol Res 167(1):27-31. https://doi.org/10.1016/j. micres.2011.02.006

Zhang YC, Zhang LW, Ma W, Yi HX, Yang X, Du M, Shan YJ, Han X, Zhang LL (2012) Screening of probiotic lactobacilli for inhibition of Shigella sonnei and the macromolecules involved in inhibition. Anaerobe 18(5):498-503. https://doi.org/10.1016/j. anaerobe.2012.08.007

Zhang CL, Liu QZ, Wang J, Chu X, Shen LM, Guo YY (2014) Epidemic and virulence characteristic of Shigella spp. with extended-spectrum cephalosporin resistance in Xiaoshan District, Hangzhou China. BMC Infect Dis 14(1):260. https://doi. org/10.1186/1471-2334-14-260

Zhao ZY, Chen Q, Zhao B, Hannah MN, Wang N, Wang YX, Xuan XF, Rui J, Chu MJ, Yu SS, Wang Y, Liu XC, An R, Pan LL, Chiang YC, Su YH, Zhao BH, Chen TM (2020) Relative transmissibility of shigellosis among male and female individuals: a modeling study in Hubei Province, China. Infect Dis Poverty 9:1-16. https ://doi.org/10.1186/s40249-020-00654-x

Zhou F, Ji B, Zhang H, Jiang H, Yang Z, Li J, Li J, Ren Y, Yan W (2007) Synergistic effect of thymol and carvacrol combined with chelators and organic acids against Salmonella Typhimurium. J Food Prot 70(7):1704-1709. https://doi. org/10.4315/0362-028X-70.7.1704

Zhu Z, Shi Y, Zhou X, Li B, Zhang J (2018) Molecular characterization of fluoroquinolone and/or cephalosporin resistance in Shigella sonnei isolates from yaks. BMC Vet Res 14(1):177. https://doi. org/10.1186/s12917-018-1500-6

Publisher's Note Springer Nature remains neutral with regard to jurisdictional claims in published maps and institutional affiliations. 